\title{
Small town
}

Half-way through a trip from East Sumba's capital Waingapu to Waikabubak in West Sumba, the road leads through a large forest. There are hardly any settlements here and the traveller has a beautiful view of Sumba's highest mountain. When the road descends and the first settlements along the road pop up, we enter Anakalang. The name refers both to a fairly large area and to the ancestral village of many of its elite: kampong Anakalang. The kampong is built on the highest hill, from where you can see the surrounding plains. Some descendants from this kampong have completely abandoned it, whereas others still have poorer relatives who live in the old kampong. They work the fields and take care of the houses and tombs in front. The families that were more successful and gained wealth and good positions through their social status and education moved to lower, new kampongs that are built close to the main road. Government officials from Anakalang drive up to their house in their four-wheel drive jeep or kijang. The new houses in the lower and wealthier kampongs have the traditional shape, but they are constructed with modern materials, at least with zink roofs.

South of the main road is a large plain. Part of it, is used to cultivate rice and the rest is a grazing field for livestock. I often heard complaints that the herds of water buffalo and horses were getting smaller each year. The introduction of hand tractors has certainly made a difference, since they offer a new and more individual way of working the land. Rice cultivation traditionally involved herding groups that all year round took care of the buffaloes. It also involved groups of women who would collectively transplant rice in the planting season until all fields of the group members were planted. Commoditization of rice cultivation brought the end of this type of mutual assistance and introduced paid land labour. With the improvements of the roads, not only the main road, but also the road to the interior land, more and different people became available for land labour. In 2004, the number of cars, busses and trucks that come to Anakalang has increased; additionally, the frequency of transport trips is much higher than ten years ago. From early morning until about $8 \mathrm{p} . \mathrm{m}$. there are small buses looking for passengers to Waikabubak. There is a big bus to Waingapu, at least three times a day. 
Continuing along the road from the east, the first side road to the north leads to and eventually ends in Memboro, on the north coast. Close to the junction is Pak Indy's house and shop. He has lived there for a long time and has tried to earn an income from the shop, his fields and any other short term job he can get, while his wife works as senior teacher in the primary school. He is a very intelligent man, but his career was blocked in 1965 after he was accused of being a communist. Their children have all moved to Java where they pursued a university education. From 2000 onwards the heavy burden of education fees disappeared and Pak Indy invested in a new house. He finished it in 2005 and it stands proudly at the junction, ready to be Anakalang's first tourist hotel. Pak Indy's shop is more or less taken over by a local policeman, who has turned the place in a shop annex café and meeting place. Allegedly it is the place where men gather at night and drink. Alcohol abuse has become a problem in Sumba only recently, but on such a large scale that it is now known with the Indonesian acronym miras (minuman keras, strong alcoholic drinks) and there are programmes to tame it. Local commentators suggest that the police who should control the miras problem are the ones who organize and benefit financially from it.

Anakalang administratively consists of several desa of which Anajiaka and Wai Bakul are closest to the main road. Each of these desa has its own primary school. Since the early twentieth century there have been schools in this area, and the result is that in the twenty-first century many people from Anakalang are well educated. The missionaries invited the children of nobility to attend their schools and children from Anakalang were among the first elected. Subsequently they received high positions in government, church or schools. The clearest example is Umbu Remu Samapati, who was the second bupati of West Sumba after independence. His kampong is one kilometre south from the main road that passes the marketplace. Its name is Kabunduk, and it is most conspicuous due to the enormous tomb of Umbu Remu at the entrance of the kampong. It is extremely large, yet modern in materials (black tiles) and traditional in shape. Umbu Remu's father's tomb is located at the other end of the plaza in this kampong. It is the largest tomb on the island. It is made of rock carved from the mountains and dragged by hundreds of people and it is 'forthrightly named 'Most Macho' (Rasi Moni) (Keane 1997:42). Umbu Remu's heavy modern tomb characterizes the type of power which is prominent in the twenty-first century, based on tradition but completely adapted to modern times.

Closer to the main road is the market place. Since the 1950s there are two markets a week. People form villages in a wide circle around Anakalang come early in the morning. They bring their produce: vegetables, eggs, areca nut, chicken and in times of trouble and when they desperately need money, they bring pigs and dogs to the market. Teenage girls from the interior villages love 
going to the market, because it is the only place where they can freely meet boys. At the market traders from town sell industrial products: cheap clothes and cosmetics, soap, sugar, kerosene. They buy the eggs and chicken to sell them again in Waikabubak. There are only a few small shops in Anakalang. Even though there are many people who linger for hours around the market, there are no restaurants or small food stalls (warung). When I asked unemployed youth why they did not start a warung, they explained that there are plenty of people in Anakalang who like to eat, but no one will pay.

The best opportunity to eat out is at feasts or funerals. When I stayed in Anakalang in 2004 an old lady had died and the funeral was set to take place in a few days. It is custom for neighbours and relatives to visit the house of the deceased and stay there for a death wake (originally to keep bad spirits away). In that week, every night around eleven youth from the neighbourhood would gather in the house officially for death wake, but allegedly also to meet each other and drink alcohol.

In Anakalang there are no facilities for middle class and modern Indonesian youth. Their number is increasing since 2000. Many children from this area studied on Java or in Kupang, the provincial capital in West-Timor. Yet, it is hard to find employment after graduation. Those who do not succeed in finding a job outside Sumba return to their parents in Anakalang. They have experienced a totally different life on Java and have problems readjusting to the simple rural life in Anakalang. Some of them turn to agriculture and make use of their time to produce as much as they can. Some work as volunteer teachers, and others just wait for a chance to get a position in a government office. These vocal youngsters at times scare the older generation. They brought ojek to Anakalang, the motorcycle taxi, along with an acceleration of the pace of life.

Further west along the road to Waikabubak is the new GKS church (see p. 37). It has been built over the last ten years and still not completely finished. What strikes every by passer is the enormous size of the building, especially compared to the houses and other buildings in Anakalang. Its design reflects the ambition of the congregations' building committee, chaired by Umbu Djima. He was able to collect donations for building the church from his wide network, in and outside Sumba. The result is a modern-shaped status symbol both for the GKS and Umbu Djima (Vel forthcoming).

Just before the northwest road junction, there used to be a post office where in the mid-twentieth century, Anakalang had telephone connection. The post office was still operative in the 1980s. Now the only post office left in West Sumba is the main one in Waikabubak. It is cheaper, faster and more reliable to give a note or a message with the busses going to town than to send a letter. The lucky few owners of cell phones send text messages instead of letters as soon as they are close to Waikabubak where there is a commu- 
nity antenna. In September 2006 such an antenna was installed in Anakalang. The post office building was converted into a private house. A young couple, a civil servant and the granddaughter of a former raja, live here with their children. They love to watch TV and since it is on whenever the electricity works, their children learn the television language faster than the vernacular language of Anakalang. 